\title{
XXX. On the culture of parsnips, and their utility in feeding cattle
}

\section{Charles Le Hardy Esq.}

To cite this article: Charles Le Hardy Esq. (1810) XXX. On the culture of parsnips, and their utility in feeding cattle , Philosophical Magazine Series 1, 35:143, 176-179, DOI: $10.1080 / 14786441008563053$

To link to this article: http://dx.doi.org/10.1080/14786441008563053

曲 Published online: 18 May 2009.

Submit your article to this journal $\sqsubset \pi$

Џ Article views: 2

Q View related articles $\sqsubset$ 
method, the ratios had been subtracted thus, $\frac{64}{81} \times \frac{5}{4}=$ $\frac{320}{324}=\frac{80}{81}$, and $\frac{5}{6} \times \frac{32}{27}=\frac{160}{162}=\frac{80}{81}$ the results would be the major comma in both instances, instead of one being a goth, and the other an $83 \frac{1}{3}$ rd part of a tone, neither of which are much different from one ninth part of what they ought to be, being altogether the produce of egregious blundering; for the major comma is known to be nearly the $9 \frac{1}{2}$ th part of a major tone, or more exactly, $9.48141 \times$ $c=\mathrm{T}$. And thus we see, that the error of a whole comma is said by this gentleman not to be perceivable by the ear! and guided as $I$ suppose by the above erroneous principle, he has added to the confusion which already reigned, as to the names of intervals, by giving many new and absurd ones; for instance, he calls $\frac{16384}{19683}$ a superfuous second, although it exceeds a minor third in magnitude, $\frac{59049}{65536}$ he calls a diminished third, although the same is less than a minor tone, or comma-deficient major second, and so of many others. At page 116 he asserts, that $1, \frac{1}{3}$ and $\frac{1}{5}$ are not the Harmonicals or "replies" of a sound, but $1, \frac{1}{3}$ and $\frac{16}{81}$ !

Hoping, Sir, that this will be the last time that I shall have to expose such gross ignorance in authors, on the nature and fundamental principles of musical calculation,

Westminstar, 12th March 1810. I remain yours, \&ac.

XXX. On the Culture of Parsnips, and their Vtility in feeding Cattle. By Charmes Le Hardy, Esq., of the Island of Jersey*

Sir, $\mathrm{H}_{\text {aving observed in the bonk of Premiums offered by }}$ the Society, that they wished for information on the culture of parsnips, which are much used in the island of Jersey;-as having practised it for many years, I take the liberty to comsmunicate what I know on the subject, with the result of some comparative experiments.

The culture of parsnips and beans is looked upon as one of the regular courses of crops in the island. There is no farmer, be the extent of his grounds ever so small, who.

* From Transactions of the Soriely for the Encontragement of Arts, Mawifactures, and Commerce, for 1809. The Society voted their silver medal to Mr. Le Hardy for this communication.

does 
does not yearly plant a proportionate quantity, for the purpose of fattening his hogs and cattle, or of feeding his milch cows.

A few years ago, the culture of potatoes was substituted by some farmers to that of parsnips, and apparently with advantage; but further experience has brought them back again to their furmer practice. Potatoes produce more weight and measure on a given extent of ground, and may be cultivated with less expense ; still the parsnip is found to answer best for the farmer's purpose. A perch of the island, which is twenty-four square feet, will produce on an average crop, seven cabots of potatoes, each weighing forty pounds; the same extent in parsnips will only average six cabots, which weigh only thirty-five pounds each, making twenty pounds weight in favour of the potatoes;-but they are not so nutritious as parsnips.

Parsnips will thrive almost any where, but better in a deep stiff loam. They are generally cultivated in the island after a crop of barley, in the following manner.-At the end of January or the beginning of February, the soil, which requires for that purpose to be stirred from the bottom, is either dug with spades after a skimming plough, or with two ploughs of different shapes following one another. The latter of the two, invented some years ago by a farmer in the island, will go to a depth of fifteen inches. In both these ways the neighbouring farmers assist each other: in the season, it is not uncommon to see forty or fifty men in one field digging after a plough. When the large plough is used, less inen are required, but more strength of cattle; two oxen and six horses are the team generally used. Those days are reckoned days of recreation, and tend to promote social intercourse among that class of men.

After the ground has been tilled in this way, it is coarsely barrowed, and a sufficient number of women are provided to plant beans. These are dibbled in rows three by three $\vdots: \vdots: \vdots: \vdots:$ at the distance of five feet from row to row. Two women may plant one vergee in a day: two vergees and a half being equal to an English acre. Three sixtenniers of parsnip seed (about $\frac{1}{7}$ of a Winchester bushel) are then sown upon each vergee, and the whole is finely harrowed.

This crop now requires no attendance till the month of May, when weeding becomes necessary. This is the most expensive part of the culture. It is generally done by hand, with a small weeding fork; and as the parsnips require to be kept very clean, the expense is proportionate to the quantity of weeds. This last summer four women were emVol. 35. No. 143. March 1810. 
ployed twenty -eight days each in weeding about five vergees. I tried a few perches with the hand-hoe, and thinned them like turnips; they proved finer than those which were hand-weeded. In Guermsey they make use of the spade for that purpose.

In the begiming of September the beans are pulled up from among the parsnips, and about the latter end the digging begins. The instrument used is the common threepronged fork. This work is done gradually as the cattle want them, till the ground requires to be cleared for sowing wheat, which after parsuips is generally done about the middle of December. They are recknned an excellent fallow for that kind of grain, and the finest crops are gencrally those which succeed them : as it is a tap-rooted plant, it does not, like the potatoe, impoverish the surface, but leaves it mellow and free from weeds, to a succeeding crop.

When parsuips require to be kept for the use of cattle, they are brouglat rly under sheds, abd will keep good without any care till the end of March. Should they require to be kept longer, they are laid in double rows over one another, their heads out a ard, with alternate strata of earth, which, when finished, have the appearance of small walls, or, if made circular, of small rowers. Those for seed are always preserved in this manner, and sometimes carrots and beets for culinary purposes.

Parsnips are not injurcd by frost ; after having been frozen, they are fit for vegetation : the only sensible alteration is their acquiring a sweeter taste, and by that pethaps becoming nore nutritive. They are given raw to bogs and to horned cattle. Though horses are fond of these roots, they are not suffered to eat them, as they make them languid, and are apt to injure their sigint. Their leaves when wet are so caustic as to blister the hands of the weeders, and sometimes to occasion a violent inflammation in the eyes and udders of the cattle feeding upon them.

Cows fed on parsnips in the winter months, give a greater quantity of milk and butter, and of better flavour, than those fed upon potatoes. The butter is nearly equal to that from spring giess. Though the root of this plant has the quality of improving that article, it must be ohserved, that the leaves give it a very disagreeable taste, which, however, is of no consequence when intended to be potted, as it goes off in a short time.

Parsnips are dangerous food for sows before they farrow, and might occasion them to lose their litter. Hogs may be fattened with them in about six weeks. It is the custom. during 
luring that time, to thicken their swill with the meal of beans and oats ground together. Pork fattened in this way is very firm, and does not waste in boiling.

Horned cattle may be fattened with parsnips in about three months. I never knew them used for sheep.

It is the general opinion in the island, that hogs or cattle fed on parsnips may be brought in a condition for slaughtering in less time, and with half the quantity that would be required of potatoes. The butchers are sensible of the superiority of the former, and will give a balfpenny per pound more for cattle fattened with them, than for such as have been fed any other way. Upon inquiry I was informed, they always contained a greater quantity of tallow.

This I believe to be a full account of the culture and use of the parsnip, and a just comparison with the potatoe. Should the Society wish any further information, either on this, or on my Telegraph, I shall think myself in duty bound to give it.

I remain, sir,

Your most obedient humble servant,

Charles le Hardy.

The above communication was accompanied with certificates of the correctness of the statements which it contains.

XXXI. Analysis of the Carlonated Chalyleate Well, lately discovered at Middleton Hall, the Seat of Sir William Paxton, Kt., near Llanurthney in Carmarthenshire. Conmunicated by Mr. Howell. The Analytical Results from an Analysis of $\mathrm{Mr}$. Ассим.

$\mathrm{M}$

EDicinal waters have from time immemorial been much resorted to by the afficted; and many traditionary as well as written accounts of their virtues have been transmitted from one age to another.

During the first efforts of science, accident seems to have given some of these waters an illegitimate value, and prejudice or fiction clothed others with mystery.

Before the Christian æra, the effects of particular waters were known; and to some, such as the fabled waters of Lethe, supernatural powers were attributed. Soon after the commencement of that $æ$ ra, medicinal springs increased every where, and superstition found in almost every situation a holy or canonized well. The first rays of reformation exposed the impotency of many, and the unchastened glare that too often leads into extremes, brought others de- 